\title{
Toxicology and safety of the tincture of Operculina alata in patients with functional constipation
}

\author{
Luciana Kelly Ximenes dos Santos, Gilmara Holanda da Cunha, Francisco Vagnaldo Fechine, \\ Andréa Vieira Pontes, Jonaina Costa de Oliveira, Fernando Antonio Frota Bezerra, \\ Manoel Odorico de Moraes, Maria Elisabete Amaral de Moraes*
}

Clinical Pharmacology Unit, Department of Physiology and Pharmacology, Faculty of Medicine, Federal University of Ceará

\begin{abstract}
The tincture of Operculina alata, popularly known as "tincture of jalapa", is used in Northeast Brazil to treat constipation and encephalic vascular accident, but it has not yet been adequately tested for safety and efficacy. The aim of this study was to evaluate the toxicology and safety of the tincture of $O$. alata in patients with functional constipation. This was a double-blind, randomized, placebo-controlled clinical trial. The study consisted of three phases: pre-treatment, treatment and post-treatment, each phase with duration of seven days. Arterial pressure, heart rate, body weight, adverse events, hematological, metabolic, liver and kidney functions were monitored. Forty patients were randomized to receive tincture of $O$. alata and 43 patients to receive placebo. There were statistical differences in the clinical aspects between groups, but these changes were not considered clinically significant. Adverse events were considered not serious and of mild intensity, especially dizziness, headache, abdominal pain and nausea. This clinical trial confirmed the safety of the tincture of $O$. alata in the pharmaceutical form and dosage tested, allowing the product to be safely used in a larger population for the assessment of its clinical efficacy.
\end{abstract}

Uniterms: Operculina alata/pharmacognosy. Operculina alata/tincture/toxicological evaluation. Operculina alata/tincture/safety. Tincture of Jalapa see Operculina alata/tincture.

A tintura de Operculina alata, popularmente conhecida como "tintura de jalapa", é usada no Nordeste do Brasil para tratar constipação intestinal e acidente vascular encefálico, mas sua eficácia e segurança ainda não foram confirmadas. O objetivo deste estudo foi avaliar a toxicologia e segurança da tintura de O. alata em pacientes com constipação intestinal funcional. Este foi um ensaio clínico duplo-cego, randomizado e controlado por placebo. O estudo consistiu de três fases: pré-tratamento, tratamento e pós-tratamento, cada fase com duração de sete dias. Foram monitorizados a pressão arterial, frequência cardíaca, peso corporal, eventos adversos e funções hematológica, metabólica, hepática e renal. Quarenta pacientes foram randomizados para receber tintura de $O$. alata e 43 pacientes para receber placebo. Houve diferenças estatísticas nos aspectos clínicos entre os grupos, contudo, estas mudanças não foram consideradas clinicamente significativas. Eventos adversos foram considerados não sérios e de leve intensidade, especialmente, cefaléia, tontura, dor abdominal e náusea. Este ensaio clínico confirmou a segurança da tintura de $O$. alata na forma farmacêutica e dosagem testada, permitindo que o produto seja testado em população maior para determinar sua eficácia clínica.

Unitermos: Operculina alata/farmacognosia. Operculina alata/tintura/avaliação toxicológica. Operculina alata/tintura/segurança. Tintura de Jalapa see Operculina alata/tintura.

\footnotetext{
*Correspondence: M.E.A. Moraes. Departamento de Fisiologia e Farmacologia, Faculdade de Medicina, Unidade de Farmacologia Clínica. Rua Coronel Nunes de Melo, 1127 - Rodolfo Teófilo - 60430-270, Fortaleza - CE, Brasil. E-mail: gpclinica@unifac.med.br
} 


\section{INTRODUCTION}

The tincture of O. alata is an extract derived from Operculina alata Urban, a plant that belongs to the Convolvulaceae family. It is found in the tropical and subtropical regions between the Antilles and Brazil and temperate regions of the Mexican Andes, and is known as jalapa. The tincture has been used as a laxative in popular medicine (Matos, 2000; Gomes et al., 2009). One of the most interesting characteristics of this family is the presence of secretory cells that secrete glycosidic resins in foliar tissue and especially in roots (Gomes et al., 2009). In fact, plant substances are potential sources of clinically important drugs (Moraes et al., 2008).

A preclinical study has demonstrated laxative activity in the hydroalcoholic extract of the O. alata tuber in mice using the intestinal motility test (Michelin, Salgado, 2004). A chronic toxicity study determined that the hydroalcoholic extract is safe in adult Wistar rats when administered orally (13 weeks) (Gonçalves et al., 2007). The tincture of $O$. alata is characterized as a stimulant or irritant laxative.

Constipation is a very common disease, affecting 2 to $27 \%$ of the population (Garrigues et al., 2004; Lembo, Camilleri, 2003; Pare et al., 2001). The definition of functional constipation in adults, according to Rome III criteria, a system developed to classify functional gastrointestinal disorders, is as follows: less than three bowel movements per week, on average, during the last three months, and/ or with excessive need for straining, hard stool, low stool weight or sensation of incomplete evacuation in more than a quarter of the evacuations (Longstreth et al., 2006).

Several classes of medicines are used for the treatment of constipation. However, it has been observed in the last decades a constant increase of the use of herbal medicines, which has been encouraging scientific studies for the discovery of new substances with therapeutic action and for the confirmation of the efficacy and safety of medicines derived from plants (Hansen et al., 2010; Ma et al., 2010; Moraes et al., 2012). The safe use of herbal drugs requires knowledge of their chemical properties and possible adverse effects (Fejzic et al., 2010; Teschke et al., 2010). Plant materials are used throughout the world as home remedies or raw materials for the pharmaceutical industry and represent a substantial proportion of the global drug market (Bosnic et al., 2007). With the continuous increase in the use of herbal medicines worldwide, the safety and quality of herbal medicines have become a major concern (Kamil et al., 2010).

Therefore, the aim of the present study was to investigate the toxicology and safety of the tincture of $O$. alata in the treatment of patients with functional constipation. It has a low cost and has been widely used indiscriminately to treat constipation, but its safety in humans has not yet been proved through clinical trials.

\section{MATERIAL AND METHODS}

\section{Patients}

This study was conducted in accordance with the Declaration of Helsinki, and the protocol was approved by the Ethics Committee of the Federal University of Ceará, in Fortaleza, Brazil, and registered under No.160/08 $(33 / 08)$. All patients gave their written informed consent and were free to withdraw from the trial at any time.

The patients were recruited from the Clinical Pharmacology Unit and submitted to a clinical evaluation to confirm the diagnosis of functional constipation, according to the Rome III criteria (Longstreth et al., 2006). The criteria for inclusion in the study were as follows: male or female, aged 18 years and older, having a body mass index (BMI) between 19 and 30, and confirmed diagnosis of functional constipation. Exclusion criteria included hypersensitivity to the study drug, addiction to drugs, constipation associated with drug treatment, use of experimental drugs in the previous 6 months, laboratory tests showing clinical abnormalities, untreated illnesses, pregnancy and lactation.

The patients maintained their routine activities and diet. They were instructed to report any adverse events, time of occurrence and use of concomitant medication. Female patients of child-bearing potential were included after confirmation of a negative pregnancy test ( $\beta$-subunit of human chorionic gonadotropin; HCG), and were recommended to use highly effective methods of birth control contraceptives during the study such as oral contraceptive and condom, intra-uterine device (IUD) and condom or diaphragm with spermicide and condom.

\section{Study design}

The randomized, double-blind, placebo controlled study, consisted of three phases - pre-treatment, treatment and post-treatment - with each phase lasting 7 days. During pre-treatment, the patients signed an informed consent form and had their diagnosis of functional constipation confirmed. The treatment phase consisted of randomization and administration of a single daily dose of $15.0 \mathrm{~mL}$ of the tincture of $O$. alata or placebo, followed by drinking $200.0 \mathrm{~mL}$ of water. The post-treatment consisted of an evaluation of the patient following drug or placebo administration. 
The tincture of O. alata $\left(\right.$ Tincture of Jalapa Sobral $\left.{ }^{\circledR}\right)$ was produced by the Sobral Pharmaceutical Laboratory, located in Piaui, Brazil. Voucher specimens (No. 58836) were deposited in the Herbarium of the Agricultural Research Company of Pernambuco. The tincture contains $O$. alata tuber as a powder in a $50 \%$ hydroalcoholic vehicle. The placebo was the hydroalcoholic vehicle. Each milliliter of the tincture consisted of $200 \mathrm{mg}$ of $O$. alata root powder, containing 1.5 to $1.9 \%$ resin glycosides, the pharmacologically active substances. The dose of $15.0 \mathrm{~mL}$, used in this study, contained between 45.0 and $57.0 \mathrm{mg}$ of resin.

The resin is obtained by hydroalcoholic extraction and has organic and inorganic constituents, which can be divided into two main parts: one $\mathrm{CHCl}_{3}$-soluble ("jalapin" or nonpolar fraction) and $\mathrm{MeOH}$-soluble ("convolvulin" or polar fraction). The action of jalapa is due to the high resin content present in the tuber, which contains glycosides that, in the presence of bile, are hydrolyzed into a sugar and aglycone, releasing the corresponding free fatty acid. Free fatty acids irritate the intestinal mucosa, increase peristalsis, and facilitate evacuation (Pereda-Miranda et al., 2006; Teske, Trentini, 1997). Separation by reverse phase HPLC shows that the active constituents are a mixture of resin glycosides (Pereda-Miranda, Bah, 2003).

\section{Safety and tolerability}

Patients were asked to record any adverse events in a diary on a daily basis. Adverse events were mapped to reference terms and body systems and coded according to the Adverse Reaction Terminology Dictionary of the World Health Organization - WHO (WHO, 2010). In addition, the occurrence of any adverse event identified through questioning of the investigator was recorded. All adverse events were assessed and recorded in detail by the investigator and reported in accordance with regulatory definitions, in terms of severity, duration and outcome, etiology and relationship to the study drug.

Laboratory tests were performed in the pre-treatment and post-treatment phases, including hemoglobin, red blood cell count, hematocrit, platelets, leukocytes, lymphocytes, basophils, eosinophils, monocytes and neutrophils and serum levels of albumin, alkaline phosphatase, total, direct and indirect bilirubin, creatinine, $\gamma$-glutamyl transferase (GGT), glucose, electrolytes $\left(\mathrm{K}^{+}, \mathrm{Na}^{+}\right)$, glutamic oxaloacetic transaminase (aspartate aminotransferase - AST) and glutamic pyruvic transaminase (alanine aminotransferase-ALT) as well the $\beta$-subunit of HCG in female patients of child-bearing potential.

Analyses were performed by a local accredited labo- ratory at each investigator site. When values for a given sample were outside the normal range, the analysis was repeated to confirm the findings. Abnormal values were recorded by the investigator on the case report form, and an assessment of its possible etiology was performed.

Systolic (SAP), diastolic (DAP) and mean arterial pressure (MAP), measured non-invasively with a sphygmomanometer, and heart rate (HR) were recorded in the pre-treatment, treatment for five days (T1, T2, T3, T4 and T5) and post-treatment, after 30 minutes of rest in a sitting position. Body weight (BW) was obtained in the pre-treatment and post-treatment phases.

\section{Statistical analysis}

The quantitative variables were initially analyzed by the Kolmogorov-Smirnov Test to verify the normality of distribution. For descriptive statistics, the mean and standard deviation for parametric data or median and interquartile range (nonparametric data) were calculated. Comparisons between groups (placebo versus jalapa) in each phase of the study (pre-treatment, treatment and posttreatment) were made using the $t$ test for unpaired variables (parametric data) or Mann-Whitney test (nonparametric variables). Comparisons between the pre-treatment and post-treatment phases in the same group were made using the $t$ test for parametric data or Wilcoxon test for nonparametric variables.

Comparisons between the three phases (pre-treatment, treatment and post-treatment) in the same group were carried out by analysis of variance (ANOVA) for repeated measurements and complemented by Tukey's multiple comparison test (parametric data) or by the Friedman test associated with Dunn's multiple comparison test (nonparametric variables). Qualitative variables were expressed as absolute and relative frequency, analyzed by Fisher's exact test. A $5 \%$ probability of a type I $(\alpha)$ error (significance level) was established, and a 2-tailed $\mathrm{P}<0.05$ was accepted as significant. The statistical software GraphPad Prism ${ }^{\circledast}$ version 5.00 was used for data processing and preparations of the graphs.

\section{RESULTS}

Of the 155 patients initially evaluated, only 83 met the inclusion criteria, where all of them were female. Forty patients were randomized to receive tincture of $O$. alata and 43 to receive placebo. Two patients in the jalapa group and five in the placebo group were lost to follow-up and so were withdrawn from the trial due to deviation from the experimental protocol. 
Patient pre-treatment characteristics were similar for the groups (expressed as mean \pm standard deviation): placebo group: $37.45 \pm 9.61$ years and BMI of $25.03 \pm 2.99$; jalapa group: 33.21 \pm 11.51 years and BMI of 24.21 \pm 3.01 .

DAP, MAP and BW did not show statistically significant differences $(\mathrm{P}>0.05)$ in the placebo and jalapa groups during the study. BW was expressed as mean \pm standard deviation: pre-treatment, placebo group: $60.80 \pm 8.30 \mathrm{~kg}$; jalapa group: $60.30 \pm 8.92 \mathrm{~kg}$ and post-treatment, placebo group: $61.06 \pm 8.27 \mathrm{~kg}$; jalapa group: $60.50 \pm 8.94 \mathrm{~kg}$ (Figure 1).

It was found that in T1, SAP observed in the jalapa group was significantly higher than in the placebo group $(* \mathrm{P}=0.04)$. In the placebo group, SAP measured at $\mathrm{T} 3$ was significantly lower $\left({ }^{+} \mathrm{P}<0.05\right)$ than that measured in the pre-treatment and post-treatment. In the post-treatment, HR in the jalapa group was significantly higher than in
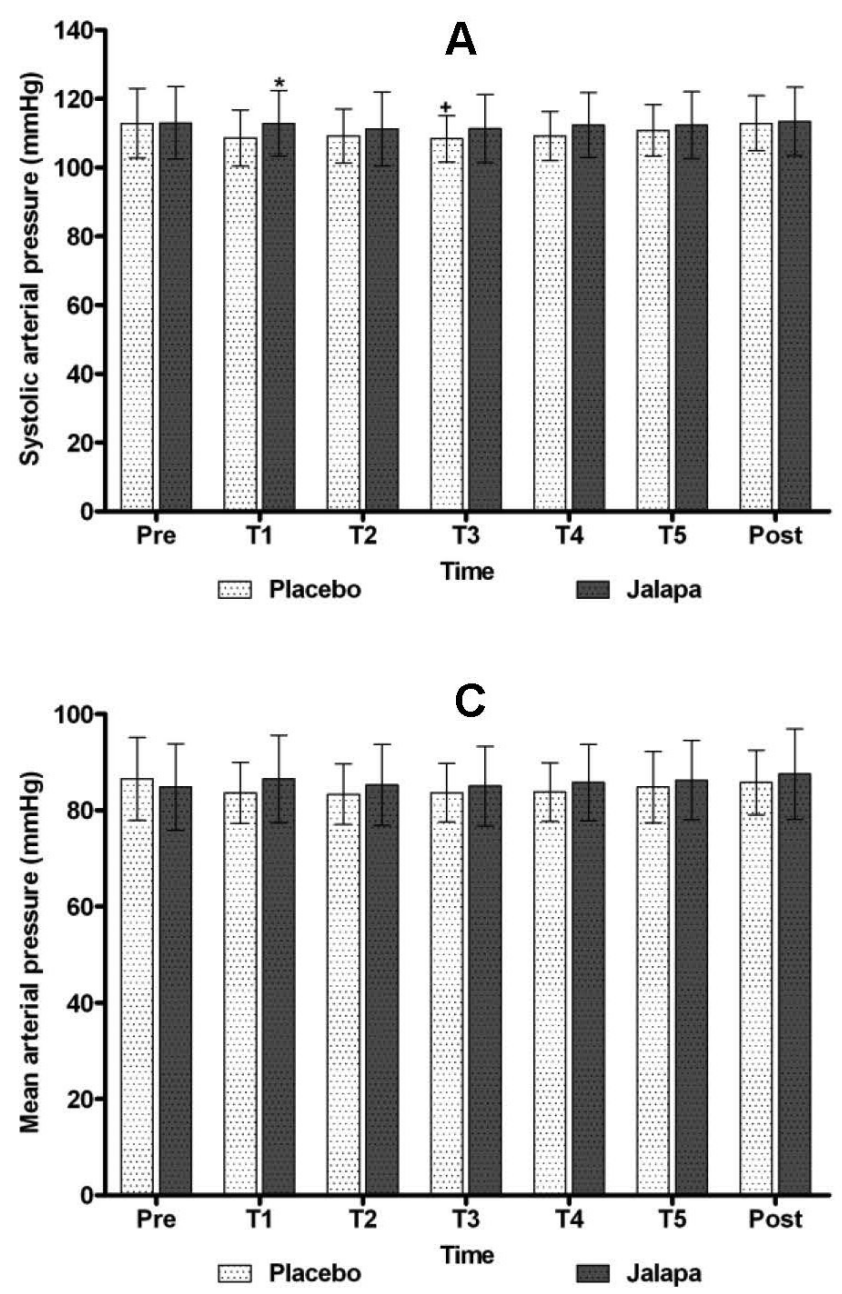

the placebo group $(* \mathrm{P}=0.03)$. In the placebo group, HR in the pre-treatment was significantly lower than at $\mathrm{T} 1$ and $\mathrm{T} 3\left({ }^{++} \mathrm{P}<0.01\right)$ and $\mathrm{T} 2$ and $\mathrm{T} 4\left({ }^{++} \mathrm{P}<0.001\right)$, and $\mathrm{HR}$ of the placebo group in the post-treatment was also found to be significantly lower compared to T2 and T4 $\left({ }^{\#} \mathrm{P}<0.05\right)$. Despite the differences, the systolic arterial pressure and the heart rate remained within normal parameters (Figure 1).

The hematological, metabolic and liver and kidney function parameters of the placebo and jalapa groups were evaluated through laboratory tests performed during the pre-treatment and post-treatment. Statistically significant differences were found, although the values were within the normal ranges, showing no clinical relevance (Tables I and II).

Adverse events were reported by 13 patients (34\%) in the jalapa group and 12 patients (31\%) in the placebo group (Table III). The most common adverse events were
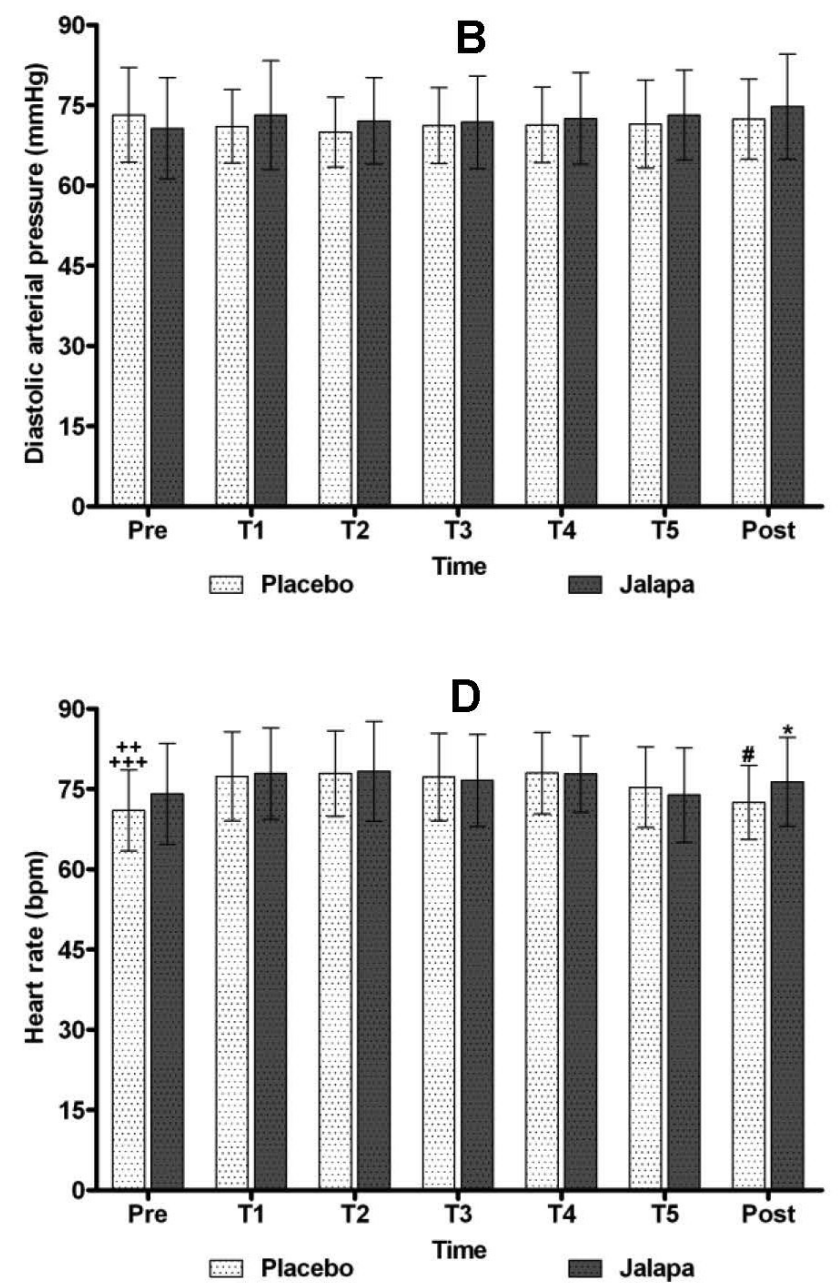

FIGURE 1 - SAP, DAP, MAP and HR of the placebo and jalapa groups in the pre-treatment, treatment and post-treatment. A ${ }^{*} \mathrm{P}=0.04$ : In T1 SAP of jalapa group $>$ placebo group. ${ }^{+} \mathrm{P}<0.05$ : In T3, PAS of placebo group $<$ pre-treatment and post-treatment. $\mathrm{B}$ and $\mathrm{C}-$ No statistically significant differences $(\mathrm{P}>0.05)$ were found between the two groups and evaluated times. $\mathrm{D}-* \mathrm{P}=0.03$ : $\mathrm{HR}$ of the post-treatment in the jalapa group $>$ placebo group. HR of the pre-treatment in the placebo group $<\mathrm{T} 1, \mathrm{~T} 3\left({ }^{++} \mathrm{P}<0.01\right)$ and T2, T4 $\left({ }^{+++} \mathrm{P}<0.001\right) ;{ }^{\#} \mathrm{P}<0.05$ : HR of the post-treatment in the placebo group $<\mathrm{T} 2$ and $\mathrm{T} 4$. 
TABLE I - Hematological test results of the placebo and jalapa groups in the pre-treatment and post-treatment, expressed as mean \pm standard deviation or median and interquartile range

\begin{tabular}{|c|c|c|c|c|c|c|c|}
\hline \multirow{2}{*}{ Parameter } & \multicolumn{3}{|c|}{ Pre-treatment } & \multicolumn{3}{|c|}{ Post-treatment } & \multirow{2}{*}{$\begin{array}{c}\text { Reference } \\
\text { values }\end{array}$} \\
\hline & Placebo & Jalapa & $P$ value $^{1}$ & Placebo & Jalapa & $P$ value $^{1}$ & \\
\hline Hemoglobin & $12.90 \pm 0.71$ & $12.85 \pm 0.74$ & 0.72 & $12.74 \pm 0.68$ & $12.81 \pm 0.74$ & 0.53 & $11.5-16.4 \mathrm{~g} / \mathrm{dL}$ \\
\hline Red blood cells & $4.42 \pm 0.35$ & $4.40 \pm 0.25$ & 0.70 & $4.34 \pm 0.31^{+}$ & $4.38 \pm 0.31$ & 0.51 & $3.9-5.810^{6} / \mathrm{mm}^{3}$ \\
\hline Hematocrit & $38.72 \pm 1.94$ & $38.43 \pm 1.85$ & 0.51 & $38.27 \pm 1.83^{+}$ & $38.32 \pm 2.12$ & 0.90 & $36.0 \%-47 \%$ \\
\hline Platelets & $274.03 \pm 58.75$ & $255.71 \pm 47.00$ & 0.13 & $266.68 \pm 57.97$ & $262.76 \pm 48.10$ & 0.74 & $150-45010^{3} / \mathrm{mm}^{3}$ \\
\hline Leukocytes & $6.83 \pm 1.46$ & $6.92 \pm 1.78$ & 0.81 & $6.47 \pm 1.40$ & $6.78 \pm 1.78$ & 0.39 & $3.6-11 \quad 10^{3} / \mathrm{mm}^{3}$ \\
\hline Lymphocytes & $33.66 \pm 7.13$ & $32.87 \pm 7.78$ & 0.64 & $34.05 \pm 8.25$ & $33.45 \pm 7.86$ & 0.74 & $20-50 \% / \mathrm{mm}^{3}$ \\
\hline Basophils & $0.00(0.00-1.00)$ & $0.00(0.00-1.00)$ & 0.90 & $0.50(0.00-1.00)$ & $1.00(0.00-1.00)$ & 0.83 & $0-3 \% / \mathrm{mm}^{3}$ \\
\hline Eosinophils & $2.00(1.75-3.00)$ & $3.00(2.00-5.00)$ & 0.07 & $3.00(2.00-4.00)^{++}$ & $3.00(2.00-4.00)$ & 0.78 & $0-6 \% / \mathrm{mm}^{3}$ \\
\hline Monocytes & $8.62 \pm 1.89$ & $8.91 \pm 2.07$ & 0.54 & $8.74 \pm 2.12$ & $8.77 \pm 2.78$ & 0.74 & $2-10 \% / \mathrm{mm}^{3}$ \\
\hline Neutrophils & $55.18 \pm 8.22$ & $53.58 \pm 8.44$ & 0.40 & $54.00 \pm 7.93$ & $54.37 \pm 9.02$ & 0.85 & $45-70 / \mathrm{mm}^{3}$ \\
\hline
\end{tabular}

${ }^{1}$ Intergroup significance. ${ }^{+} \mathrm{P}<0.05$ and ${ }^{++} \mathrm{P}=0.01$ : in relation to pre-treatment in the same group.

TABLE II - Metabolic and liver and kidney function laboratory test results of the placebo and jalapa groups in the pre-treatment and post-treatment, expressed as mean \pm standard deviation

\begin{tabular}{|c|c|c|c|c|c|c|c|}
\hline \multirow{2}{*}{ Parameter } & \multicolumn{3}{|c|}{ Pre-treatment } & \multicolumn{3}{|c|}{ Post-treatment } & \multirow{2}{*}{$\begin{array}{c}\text { Reference } \\
\text { values }\end{array}$} \\
\hline & Placebo & Jalapa & $P$ value $^{1}$ & Placebo & Jalapa & $P$ value $^{1}$ & \\
\hline Albumin & $4.45 \pm 0.19$ & $4.44 \pm 0.25$ & 0.97 & $4.42 \pm 0.20$ & $4.43 \pm 0.23$ & 0.82 & $3.4-4.8 \mathrm{~g} / \mathrm{dL}$ \\
\hline Bilirubin total & $0.61 \pm 0.21$ & $0.57 \pm 0.20$ & 0.45 & $0.59 \pm 0.19$ & $0.49 \pm 0.19^{+}$ & $0.02 *$ & $\leq 1.1 \mathrm{mg} / \mathrm{dL}$ \\
\hline Bilirubin direct & $0.14 \pm 0.06$ & $0.14 \pm 0.06$ & 0.83 & $0.15 \pm 0.06$ & $0.12 \pm 0.06^{+}$ & 0.23 & $\leq 0.3 \mathrm{mg} / \mathrm{dL}$ \\
\hline Creatinine & $0.69 \pm 0.13$ & $0.66 \pm 0.11$ & 0.22 & $0.70 \pm 0.13$ & $0.66 \pm 0.11$ & 0.13 & $0.6-1.2 \mathrm{mg} / \mathrm{dL}$ \\
\hline GGT & $22.75 \pm 14.60$ & $15.88 \pm 7.16$ & $0.01 *$ & $22.51 \pm 15.90$ & $16.79 \pm 8.60$ & 0.05 & 5-36 U/L \\
\hline Glucose & $86.87 \pm 7.85$ & $84.97 \pm 7.38$ & 0.21 & $88.37 \pm 8.43$ & $84.18 \pm 5.36$ & $0.02 *$ & $70-99 \mathrm{mg} / \mathrm{dL}$ \\
\hline $\mathrm{K}^{+}$ & $4.22 \pm 0.34$ & $4.09 \pm 0.31$ & 0.09 & $4.12 \pm 0.30$ & $4.14 \pm 0.28$ & 0.78 & $3.5-5.5 \mathrm{mEq} / \mathrm{L}$ \\
\hline $\mathrm{Na}^{+}$ & $139.34 \pm 1.79$ & $139.47 \pm 1.89$ & 0.75 & $139.53 \pm 2.31$ & $139.53 \pm 1.35$ & 1.00 & $135-145 \mathrm{mEq} / \mathrm{L}$ \\
\hline
\end{tabular}

${ }^{1}$ Intergroup significance. ${ }^{*} \mathrm{P}<0.05$ and ${ }^{+} \mathrm{P}<0.05$ : in relation to pre-treatment in the same group.

TABLE III - Adverse events reported by the patients in the jalapa and placebo groups

\begin{tabular}{|c|c|c|c|}
\hline Event & Placebo group & Jalapa group & Significance \\
\hline$\overline{\text { Dizziness }}$ & $5(13.15 \%)$ & $8(21.05 \%)$ & $\mathrm{P}=0.543$ \\
\hline Headache & $4(10.52 \%)$ & $4(10.52 \%)$ & $\mathrm{P}=1.000$ \\
\hline Nausea & $4(10.52 \%)$ & $0(0.00 \%)$ & $\mathrm{P}=0.115$ \\
\hline Drowsiness & $0(0.00 \%)$ & $2(5.26 \%)$ & $\mathrm{P}=1.000$ \\
\hline Asthenia & $0(0.00 \%)$ & $2(5.26 \%)$ & $\mathrm{P}=0.493$ \\
\hline
\end{tabular}


dizziness, headache, abdominal pain and nausea. In the statistical analysis by Fisher's exact test, there were no significant differences between the proportion of patients who had adverse events in the jalapa and the placebo groups, demonstrating the safety of using the tincture of O. alata. All adverse events were considered not serious, of mild intensity and attributed to the presence of alcohol in the formulation. No patient was withdrawn from the study due to adverse events.

\section{DISCUSSION}

The tincture of $O$. alata has been used indiscriminately in popular medicine through self-medication in the treatment of constipation and other diseases, such as bronchitis, asthma and cerebrovascular disease, with no confirmation of its safety and efficacy. This double-blind, randomized, placebo-controlled clinical trial is the first study to evaluate the toxicology and safety of tincture of $O$. alata in patients with functional constipation. The tincture of $O$. alata is classified as an irritant laxative or stimulant of the gastrointestinal tract. This study was conducted in patients with constipation because even a laxative dose could cause diarrhea in healthy subjects. The period of treatment was seven days, because an irritant laxative should not be recommended for chronic or prolonged use (Pasricha, 2005).

The most commonly used drugs belonging to this class of irritant or stimulant laxatives are anthraquinones, mainly represented by senna and diphenylmethane derivatives, such as bisacodyl. Stimulant laxatives increase intestinal motility and secretions by stimulating the colonic myenteric plexus and altering fluid and electrolyte flow (Tack, Müller-Lissner, 2009).

Demographic data showed that all patients of the study were female with ages ranging from 21 to 47 years in both groups. The occurrence of only female patients is due to the high prevalence of women with constipation. This is justified by studies that report that constipation is more common in women (Pasricha, 2005; Klaschik et al., 2003). The prevalence may be three times higher in females than in males, mainly associated with cultural factors (Higgins, Johanson, 2004).

Tolerance to stimulant laxatives may occur mostly in patients with severe slow time colonic transit, in which other types of laxatives are ineffective, but tolerance is uncommon in the majority of users (Müller-Lissner et al., 2005). The intermittent use of stimulant laxatives seems to be well accepted by investigators, sponsors, ethical committees and regulatory authorities because they have been used as rescue therapy in many clinical trials with constipation and in irritable bowel syndrome (Tack, Müller-Lissner, 2009). Also, alternative medicines are increasingly popular due to the fact that the compounds are natural, well tolerated and lack side effects (Kalus et al., 2010).

The clinical examinations, physical evaluation and laboratory tests performed before and after the research did not show toxicity signs in the various organs and systems assessed. Systolic arterial pressure, heart rate, red blood cells, hematocrit, eosinophils, glucose, total bilirubin, direct and indirect bilirubin showed statistically significant changes. Nevertheless, the results remained within normal limits and were not clinically significant.

The adverse events reported for the jalapa group and placebo group were all classified as non-serious and mild. The most common adverse events were dizziness, headache, abdominal pain and nausea, not considered clinically significant and actually related to the alcohol concentration in the formulation of the phytotherapic medicine. Alcohol is a depressant of the central nervous system and can cause the observed effects depending on the dose ingested (Pasricha, 2005). These events did not result in any withdrawn from the trial. Abdominal pain, nausea and other disorders of the gastrointestinal tract can also be related to the resin present in the tincture of $O$. alata. The action of jalapa is due to the high resin content present in the tuber, a stimulant of the intestinal mucosa, increasing peristalsis and facilitating evacuation (Tesk, Trentini, 1997). This action may have caused the abdominal pain and the other gastric disorders reported by the subjects of the study.

The observed adverse events have also been reported for other stimulant laxatives. In the assessment of the safety of bisacodyl and Smooth Move ${ }^{\circledR}$, which contains senna (Cassia angustifolia Vahl), it was observed that most adverse events were gastrointestinal tract disorders (Kienzle-Horn et al., 2006; Bub et al., 2006).

In a preclinical study of acute and chronic toxicology in Wistar rats, there were no toxic effects at the doses of hydroalcoholic extract of $O$. alata tested, which were 25 times higher than the therapeutic dose recommended for the laxative effect. It did not modify the biochemical and hematological profiles of the animals after treatment, showing it to be a safe phytotherapeutic product (Gonçalves et al., 2007).

Tincture of $O$. alata has proved effective in acute treatment of functional constipation in humans through a randomized, double-blind, and placebo-controlled clinical trial. This phytotherapeutic medication showed a significant beneficial effect, representing an alternative for the acute treatment of functional constipation (Cunha et al., 2011).

There were difficulties in comparing the results 
obtained with other studies due to the existence of only preclinical toxicology studies of the tincture of $O$. alata. It was not possible to determine the tolerance and dependence of this phytotherapeutic medicine when used for extended periods, since it was only tested for acute treatment. Furthermore, we suggest a reassessment of the current formulation of the phytotherapeutic medicine to reduce the alcohol concentration and prevent potential adverse events related to alcohol.

\section{CONCLUSIONS}

This clinical trial confirmed the safety of the tincture of $O$. alata in the pharmaceutical form and dosage tested, allowing the product to be safely used in a larger population. In addition, phytotherapeutic medicines can be of great economic, medicinal, and social importance, when produced with rigorous quality control and used properly by patients.

\section{REFERENCES}

BOSNIĆ, T.; SOFTIC, D.Z.; JERG-SIMANOVIC, D.; PILIPOVIC, S. The microbiological quality of herbal teas and herbal medicinal products. Planta Med., v.9, p.73, 2007.

BUB, S.; BRINCKMANN, J.; CICCONETTI, G.; VALENTINE, B. Efficacy of an herbal dietary supplement (Smooth Move) in the management of constipation in nursing home residents: A randomized, double-blind, placebo-controlled study. J. Am. Med. Dir. Assoc., v.7, n.9, p.556-561, 2006.

CUNHA, G.H.; FECHINE, F.V.; SANTOS, L.K.X.; PONTES, A.V.; OLIVEIRA, J.C.; MORAES, M.O.; BEZERRA, F.A.F.; MORAES, M.E.A. Efficacy of the tincture of jalapa in the treatment of functional constipation: a double blind, randomized, placebo-controlled study. Contemp Clin Trials, v.32, n.2, p.153-159, 2011.

FEJZIC, J.; EMMERTON, L.; TETT, S.E. Towards concordance in healthcare: perspectives of general practitioners, complementary and alternative medicine practitioners and pharmacists in Australia. J. Clin. Pharm. Ther., v.35, n.3, p.309-321, 2010.

GARRIGUES, V.; GÁLVEZ, C.; ORTIZ, V.; PONCE, M.; NOS, P.; PONCE, J. Prevalence of constipation: agreement among several criteria and evaluation of the diagnostic accuracy of qualifying symptoms and self-reported definition in a population-based survey in Spain. Am. J. Epidemiol., v.159, n.5, p.520-526, 2004.
GOMES, A.M.M.; SILVA, P.L.; SOARES, S.A.; SILVA, C.E.M.; GALLÃO, M.I.; GERMANI, R.; RICARDO, N.M.P.S. Isolation and physico-chemical and rheological characterization of the Brazilian jalap starch (Operculina tuberosa Meisn.). Carbohydr. Polymer, v.77, n.4, p.885890, 2009.

GONÇALVES, E.S.; SILVA, E.J.R.; AGUIAR, F.J.S.; DIMECH, G.S.; ROLIM-NETO, P.J.; FRAGA, M.C.C.A.; LAFAYETTE, S.S.L.; WANDERLEY, A.G. Chronic toxicological evaluation of the hydroalcoholic extract of Operculina alata (Ham.) Urban on biochemical and hematological parameters in female Wistar rats. Latin America J. Pharm., v.26, n.3, p.369-374, 2007.

HANSEN, D.; HARAGUCHI, M.; ALONSO, A. Pharmaceutical properties of "sucupira" (Pterodon spp.). Braz. J. Pharm. Sci., v.46, n.4, p.607-616, 2010.

HIGGINS, P.D.; JOHANSON, J.F. Epidemiology of constipation in North America: a systematic review. Am. J. Gastroenterol., v.99, n.4, p.750-759, 2004.

KALUS, U.; KIESEWETTER, H.; RADTKE, H. Effect of CYSTUS052 and green tea on subjective symptoms in patients with infection of the upper respiratory tract. Phytother. Res., v.24, n.1, p.96-100, 2010.

KAMIL, M.; NAJI, M. Counterfeit herbal products - a global risk. Planta Med., v.5, p.76 (P115), 2010.

KIENZLE-HORN, S.; VIX, J.M.; SCHUIJT, C.; PEIL, H.; JORDAN, C.C.; KAMM, M.A. Efficacy and safety of bisacodyl in the acute treatment of constipation: a double-blind, randomized, placebo-controlled study. Alim Pharmacol. Therap., v.23, n.10, p.1479-1488, 2006.

KLASCHIK, E.; NAUCK, F.; OSTGATHE, C. Constipation: modern laxative therapy. Support Care Cancer, v.11, n.11, p.679-685, 2003.

LEMBO, A.; CAMILLERI, M. Chronic constipation. NEJM, v.349, n.14, p.1360-1368, 2003.

LONGSTRETH, G.F.; THOMPSON, W.G.; CHEY, W.D.; HOUGHTON, L.A.; MEARIN, F.; SPILLER, R.C. Functional bowel disorders. Gastroenterol., v.130, n.5, p.1480-1491, 2006. 
MA, C.; BI, K.; SU, D.; JI, W.; ZHANG, M.; FAN, X.; WANG, C.; CHEN, X. Serum and kidney metabolic changes of rat nephrotoxicity induced by morning glory seed. Food Chem. Toxicol., v.48, n.10, p.2988-2993, 2010.

MATOS, F.J.A. Plantas medicinais: guia de seleção e emprego de plantas usadas em fitoterapia no nordeste do Brasil. Fortaleza: Imprensa Universitária Universidade Federal do Ceará, 2000. p.185-187.

MICHELIN, D.C.; SALGADO, H.R.N. Evaluation of the laxative activity of Operculina macrocarpa L. Urban (Convolvulaceae). Braz. J. Pharmacognosy, v.14, n.2, p.105-109, 2004.

MORAES, M.E.A.; BEZERRA, M.M.; FROTA BEZERRA, F.A.; MORAES, R.A.; CAVALCANTI, P.P.; UCHOA, C.R.A.; LIMA, F.A.V.; MORAES, M.O. Safety evaluation of Elixir paregorico $\AA$ in healthy volunteers: a phase I study. Hum. Exp. Toxicol., v.27, n.10, p.751-756, 2008.

MORAES, M.E.A.; CUNHA, G.H.; BEZERRA, M.M.; FECHINE, F.V.; PONTES, A.V.; ANDRADE, W.S.; FROTA BEZERRA, F.A.F.; MORAES, M.O; CAVALCANTI, P.P. Efficacy of the Mentha crispa in the treatment of women with Trichomonas vaginalis infection. Arch. Gynecol. Obstet. v.286, n.1, p.125-130, 2012.

\section{MÜLLER-LISSNER, S.A.; KAMM, M.A.; SCARPIGNATO,} C.; WALD, A. Myths and misconceptions about chronic constipation. Am. J. Gastroenterol., v.100, n.1, p.232-242, 2005 .

PARE, P.; FERRAZZI, S.; THOMPSON, W.G.; IRVINE, E.J.; RANCE, L. An epidemiological survey of constipation in Canada: definitions, rates, demographics and predictors of health care seeking. Am. J. Gastroenterol., v.96, n.11, p.3130-3137, 2001.
PASRICHA, P.J. Treatment of disorders of bowel motility and water flux; antiemetics; agents used in biliary and pancreatic diseases. In: Goodman \& Gilman's the pharmacological basis of therapeutics. New York: Mc Graw Hill, 2005. section VI, p.983-1008.

PEREDA-MIRANDA, R.; BAH, M. Biodynamic constituents in the Mexican morning glories: purgative remedies transcending boundaries. Curr. Top. Med. Chem., v.3, n.2, p.111-131, 2003.

PEREDA-MIRANDA, R.; FRAGOSO-SERRANO, M.; ESCALANTE-SÁNCHEZ, E.; HERNÁNDEZ-CARLOS, B.; LINARES, E.; BYE, R. Profiling of the resin glycoside content of Mexican jalap roots with purgative activity. $J$. Nat. Prod., v.69, n.10, p.1460-1466, 2006.

TACK, J.; MÜLLER-LISSNER, S. Treatment of chronic constipation: current pharmacologic approaches and future direction. Clin. Gastroenterol. Hepatol., v.7, n.5, p.502508, 2009.

TESCHKE, R.; FUCHS, J.; BAHRE, R.; GENTHNER, A.; WOLFF, A. Kava hepatotoxicity: comparative study of two structured quantitative methods for causality assessment. $J$. Clin. Pharm. Ther, v.35, n.5, p.545-563, 2010.

TESK, M.; TRENTINI, A.M.M. Compêndio de fitoterapia. Paraná: Herbarium, 1997. p.190-191.

WORLD HEALTH ORGANIZATION. WHO guidelines on safety monitoring of herbal medicines in pharmacovigilance systems. Available at: <http://apps.who.int/medicinedocs/ assoc/s7148e/s7148e.pdf>. Accessed on: 25 Nov 2010.

Received for publication on $31^{\text {st }}$ October 2011 Accepted for publication on $28^{\text {th }}$ March 2012 